\title{
SUURGILDI LIIKMESKONNAST JA KAUPMEHE SOTSIAALSEST KARJÄÄRIST HILISKESKAEGSES TALLINNAS
}

\begin{abstract}
Anu MÄND
Tallinna Ülikooli Ajaloo Instituut, Rüütli 6, 10130 Tallinn, Eesti; anu.mand@ai.ee

Senises ajalookirjanduses on keskaegse Liivimaa linnade suurgilde (sh Tallinna oma) defineeritud kui linnakodanikest (suur)kaupmeeste korporatsioone. Tallinna allikate analüüs aga näitab, et gildi liikmeskond oli palju mitmekesisem, hõlmates lisaks kaupmeestele ka vaimulikke, linnaametnikke, aadlikke, kipreid ja kunstnikke, aga ka teiste linnade (nt Tartu, Narva, Uus-Pärnu) raehärrasid. Selgub, et sugugi kõik gildivennad polnud Tallinna kodanikud. Gildi liikmeteks loeti ka naisi, ehkki nende õigused olid meestega võrreldes piiratud.

Teise teemana on artiklis käsitletud kaupmeeste sotsiaalse karjääri võimalusi: nende üleminekut ühest korporatsioonist teise ja edenemist korporatsioonisiseses hierarhias.
\end{abstract}

Keskaegses linnas oli gildidel väga tähtis osa. Just nende korporatsioonide kaudu said inimesed osa linnakogukonda kuulumise hüvedest. Gildid kaitsesid oma liikmete ametialaseid huve, kuid pakkusid ka sotsiaalset turvalisust, kandes hoolt abivajavate liikmete ning nende perekondade eest ja korraldades oma liikmete matuseid. Korporatsiooni religioosne külg avaldus altari(te) rajamises, teatud pühakute kultuse edendamises, ühiselt missadel ja palvustel osalemises, surnumissade ja hingepalvete tellimises jne. Gildide ülesandeks oli ka seltsielu korraldamine, mis kulmineerus iga-aastaste suurte pidustuste ehk jootudega. Kõik sellised ühised tegevused tugevdasid gildi liikmete kokkukuuluvustunnet ja ühiseid väärtusi.

Erinevalt paljudest Põhja- ja Lääne-Euroopa riikidest, kus gildid reformatsiooni tagajärjel kas hääbusid või saadeti väevõimuga laiali, jäid Eestis (samuti Lätis) suuremad, st ametialased gildid püsima ja tegutsesid 1920. aastani, mil nad seisuste kaotamise seaduse tagajärjel suleti. Tänu gildide pikale ajaloole ja osalt ka nende arhiivi õnnelikule saatusele on meie päevini säilinud dokumentide hulk märkimisväärne, eriti Tallinnas. See võimaldab Tallinna gildide ajalugu, sealhulgas nende tegutsemist keskajal, uurida palju põhjalikumalt, kui see on võimalik näiteks Skandinaavia maade või Saksamaa gildide puhul. Hoolimata võrdlemisi rikkalikust allikmaterjalist, ei ole aga Tallinna gildide kohta käivate kirjutiste arv 
eriti suur, seda isegi linna tähtsaima korporatsiooni - Suurgildi - puhul. Tänini on kõige põhjalikumaks ülevaateks jäänud 1885. aastast pärinev Eugen von Nottbecki eessõna gildi skraade editsioonile. ${ }^{1}$ Mõistagi on Suurgildist juttu ka teisi Tallinna gilde või linna ajalugu puudutavates käsitlustes ${ }^{2}$, ent ühtki spetsiaalselt sellele gildile pühendatud uuemat uurimust ei ole. ${ }^{3}$

Suurgildi (sks Große Gilde; kuni 15. sajandi lõpuni Kindergilde) ajaloos on palju vaidlusaluseid küsimusi, sh gildi asutamisaeg. Käesolev artikkel gildi tekkimise ja varasema ajaloo probleemistikul siiski ei peatu. Samuti jäävad kõrvale gildi suhted kiriku, linnavõimude ja teiste gildidega. Artiklis keskendutakse eelkõige gildi liikmeskonnaga seonduvatele küsimustele, millele samuti pole senises ajalookirjanduses piisavalt tähelepanu osutatud. Keskaegsest Suurgildist on alati räägitud kui kaupmeeste organisatsioonist. ${ }^{4}$ Siiski näitavad allikad, et see ei olnud sajaprotsendiliselt nii. Käesoleva artikli eesmärgiks ongi välja selgitada, kes lisaks kaupmeestele võisid veel gildi kuuluda.

Teine teema, mida artiklis käsitletakse, ei ole seotud ainult Suurgildiga, vaid kaupmeeste sotsiaalse karjääriga laiemalt. Sotsiaalse karjäri all peetakse silmas inimese liikmeksolekut gildis või vennaskonnas, edenemist korporatsioonisiseses hierarhias ja ühest korporatsioonist teise liikumist. Selle teemaga haakub ka küsimus, kuidas olid sellised olulised sündmused inimese elus nagu kodanikuks saamine, abiellumine ja Suurgildi astumine omavahel seotud. Tallinn on üks väheseid linnu Põhja-Euroopas, kus allikad võimaldavad vähemalt kodanikkonna koorekihti kuuluvate meeste elukäiku hiliskeskajal küllalt detailselt jälgida ja eelnimetatud probleemistikku lahata.

\section{TALLINNA SUURGILDI LIIKMESKOND KESKAJAL}

Gildi liikmeskonna kohta on võimalik järeldusi teha esiteks normatiivsete allikate põhjal, milleks on Suurgildi ning Lauagildi skraad ja nende täiendused. Suurgildi ja selle juurde kuuluva heategevusliku loomuga Lauagildi koos käsitlemine on vältimatu, sest nende liikmeskond kattus kas täielikult või vähemalt suures

1 Nottbeck, E. v. Die alten Schragen der grossen Gilde zu Reval. Reval, Kluge \& Ströhm, 1885, 3-39.

2 Nt Margus, A. Tallinna Linnaarhiivi kataloog, IV. Kanuti gildi arhiiv. Tallinn, Tallinna Linnaarhiiv, 1938; Tiik, L. Tallinna gildidest ja nende kinnistuist. - Tartu Riikliku Ülikooli Toimetised, 1958, 70, 3-38; Johansen, P., Mühlen, H. v. z. Deutsch und Undeutsch im mittelalterlichen und frühneuzeitlichen Reval. Köln, Böhlau, 1973.

3 Erandiks on kaupmeeste korporatsioonide, sh Suurgildi pidustusi käsitlev monograafia: Mänd, A. Pidustused keskaegse Liivimaa linnades 1350-1550. (Tallinna Linnaarhiivi Toimetised, 7.) Tallinn, Eesti Keele Sihtasutus, 2004.

${ }^{4}$ Nt Nottbeck, E. v. Die alten Schragen, 10-12; Johansen, P., Mühlen, H. v. z. Deutsch und Undeutsch, 65; Mühlen, H. v. z. Zur Frühgeschichte der Revaler Gilden. - Reval: Handel und Wandel vom 13. bis zum 20. Jahrhundert. Hrsg. N. Angermann, W. Lenz. Lüneburg, Institut Nordostdeutsches Kulturwerk, 1997, 15-16. 
osas. Nimelt on Lauagildi vanimas, 1363. aasta skraa esimeses punktis öeldud, et gildi liikmeks võivad saada üksnes Suurgildi liikmed. ${ }^{5}$ Kas kõik Suurgildi liikmed said Lauagildi liikmeteks ja kas gildil oli ka n-ö auliikmeid, kes ei pruukinud olla Suurgildi liikmed, skraast siiski ei selgu.

Teise grupi moodustavad tegelikku elu peegeldavad allikad - Suurgildi ja Lauagildi arve- ja vendaderaamatud, kus on üles loetud uued vennad ja jootudel osalejad. Vanim neist on Lauagildi vendaderaamat aastaist 1364-1549, kus on üles tähendatud jõulu- ja vastlajootudel vastu võetud uued vennad. ${ }^{6}$ Lisaks on selles ülestõusmispühade ajal kirja pandud eelmise aasta jooksul surnud liikmed. Teiseks peamiseks allikaks on Suurgildi arveraamat aastaist 1509-1603, kuhu on kirja pandud jõulu- ning vastlajootudel osalejad ja uued vennad. ${ }^{7}$ Mõlemast allikast saab väärtuslikku teavet ka gildi juhtkonna ja teiste ametimeeste kohta, täiendavaid andmeid leiab ka Suurgildi oldermanniraamatust ja mõlema gildi arveraamatutest. $^{8}$ Kõigi nimetatud allikate põhjal on võimalik gildi liikmeskonda detailsemalt uurida.

Linna eliitkorporatsioonina hoidis Suurgild distantsi endast sotsiaalselt positsioonilt madalamate elanikkonnakihtidega. Juba vanimas, 14. sajandi teisest poolest pärinevas skraas oli rangelt keelatud eestlaste "kutsumine" gildi. ${ }^{9}$ Võrdluseks võib tuua Riia Suurgildi vanimas skraas (1354) leiduvad sätted: gildi liikmeteks oli keelatud võtta käsitöölisi ja preestreid, samuti mittesakslasi. Neid, kes töötasid palga eest, ei tohtinud gildimajja isegi külla kutsuda. ${ }^{10}$ Aja jooksul võttis Tallinna Suurgild vastu uusi piiranguid: 1423. aastal otsustas gild kraamikaupmehi oma ridadesse enam mitte võtta. ${ }^{11}$ (Tõenäoliselt kolisid viimased üle Kanuti gildi, kus veel 16. sajandi esimesel veerandil on nimetatud kaupmeeste ühendust. $^{12}$ ) 1541. aastal otsustati, et kui keegi gildivendadest kaupleb üldtunnustatud tavasid rikkudes, tuleb ta gildist välja heita. ${ }^{13}$

5 Nottbeck, E. v. Die alten Schragen, 64, § 1, 104, § 1. Sama nõue on kirjas ka Riia Lauagildi vanimas skraas. Mänd, A. Pidustused, 59.

6 Mitgliederbuch nebst Satzungen und chronikalischen Nachrichten 1364-1549. Tallinna Linnaarhiiv (edaspidi TLA), f 191, n 2, s 1.

7 Rechnungen und Brüderverzeichnisse 1509-1603. TLA, f 191, n 2, s 15.

8 TLA, f 191, n 2, s 3 Zuhauer-Rechnungsbuch der Tafelgilde 1514-1563; s 16 Buch des Ältermanns der Großen Gilde über Einnahmen und Ausgaben 1425-1532; s 19 Maigrafenbuch 1527-1543; s 20 Penninck-Schafferbuch 1533-1638; n 1, s 193 Rechnungen der Tafelgilde $1482-1554$.

9 Nottbeck, E. v., 45, § 53. Sama korratakse ka 1528. a skraas. Samas, 81, § 42. Määruse sõnastuse põhjal pole küll selge, kas see tähendab, et eestlasi ei tohi gildi liikmeks võtta või ei tohi neid lihtsalt gildi ruumidesse lasta. Tähelepanu väärib ka, et skraas on kasutatud sõna eestlased; valdavalt kasutati Liivimaa keskaegsetes allikates nimetust mittesakslased.

10 Stieda, W., Mettig, C. Schragen der Gilden und Aemter der Stadt Riga bis 1621. Riga, Häcker, 1896, 314, §5-6, 316, § 35.

11 Nottbeck, E. v. Die alten Schragen, $48, \S 70$.

12 Mänd, A. Tallinna Kanuti gild ja selle oldermannid keskajal. - Modus vivendi, II. Vana Tallinn, XVI (XX). Tallinn, Estopol, 2005, 137.

13 Nottbeck, E. v. Die alten Schragen, 61, § 93. 
Mitu määrust algab sõnadega: "Kes on meie (gildi)vend, olgu ta kodanik või külaline (borger edder gast)." ${ }^{14}$ See tõendab, et gildi liikmeks võisid saada ka "külalised" - reeglina mõisteti hansaruumis nende all mujalt tulnud kaupmehi, kes olid teiste linnade kodanikud. ${ }^{15} 1540$. aasta määruses on kirjas, et kui võõrad laevakaptenid (kiprid) või hea kuulsusega sellid tahavad gildi liikmeks saada, ei tohi neid tagasi lükata, ent kui nad soovivad edaspidi Tallinna kodanikuks saada, peavad nad esmalt oma "sündi tõendama" (st esitama sünnikirja, mis tõendab põlvnemist vabade vanemate ausast abielust). ${ }^{16}$

Normatiivsete allikate järgi otsustades koondas Suurgild hiliskeskajal oma ridadesse eelkõige kaupmehi, kelle staatus oli kõrgem kui kraamikaupmeeste oma (seega suur- ja keskkaupmehi, kes tegelesid peamiselt kaugkaubandusega).

Järgnevalt vaatleme, kas ja kuivõrd vastas normides kirjapandu tegelikkusele. Enne aga lühidalt gildi liikmeskonna suurusest. Suurgildi liikmete arvu kohta 14. ja 15. sajandil puuduvad andmed. Alles 16. sajandist, täpsemalt alates 1509. aastast, on säilinud jõulu- ja vastlajootudel osalejate nimekirjad, mille põhjal saab kindlaks määrata gildi ligikaudset suurust (ligikaudset sellepärast, et tõenäoliselt ei osalenud jootudel sada protsenti liikmetest, põhjuseks näiteks reis, haigus või kõrge iga). Kui 16. sajandi esimesel veerandil võttis jootudest osa keskmiselt sada meest, siis järgnevate aastakümnete jooksul tõusis see arv 120-140-ni ja 1540. aastate keskpaigas koguni 150 meheni. ${ }^{17}$ Seega võib, hoolimata mitmest 16. sajandi esimesel poolel linna tabanud katkuepideemiast ${ }^{18}$, täheldada gildi liikmeskonna pidevat suurenemist.

Lauagildi vanimas, 1364. aastast pärinevas liikmete nimekirjas on 86 venda, mistõttu võib oletada, et kirjas on kõik või vähemalt enamik liikmeid. ${ }^{19}$ Edaspidi on üles tähendatud uued vennad. 1364.-1424. aasta andmed on kirja pandud tagantjärele, ühe ja sama käega. Alates 1430. aastast on uusi vendi kirja pandud kaks korda aastas, vastla- ja jõulujootudel. ${ }^{20}$ Meie jaoks on esmatähtis küsimus, kas Lauagildi uued vennad on samastatavad Suurgildi uute vendadega. Kui võrrelda Lauagildi vendaderaamatu ja Suurgildi arveraamatu kattuvaid aastaid, st vahemikku 1509-1549, siis ilmneb, et uued liikmed on tõepoolest peaaegu alati samad. ${ }^{21}$

14 Nottbeck, E. v. Die alten Schragen, 49, § 73, 50, § 80, 51, § 82, § 84. Vt ka samas, 83, § 56-57.

Ebel, W. Lübisches Recht. Bd. 1. Lübeck, Schmidt-Römhild, 1971, 278.

Nottbeck, E. v. Die alten Schragen, 61, § 87. Sünnikirja kohta vt ka 60, § 85, 61, § 89, § 95.

Mänd, A. Pidustused, 138, joon 9. Kui võrrelda neid andmeid Mustpeade vennaskonna jootudel osalejate arvuga samal perioodil (samas, joon 8), ilmneb, et mustpäid oli esiteks vähem ja teiseks kõikus nende arv nii aastate kui ka ühe talve pidustuste jooksul üsna tugevasti, mis on mustpeade noorust ja suuremat mobiilsust arvestades ka ootuspärane. Suurgildi kui peamiselt linnakodanikke ühendava korporatsiooni jootudel osalejate arv oli palju stabiilsem.

18 Johansen, P., Mühlen, H. v. z. Deutsch und Undeutsch, 49, 275.

19 TLA, f 191, n 2, s 1, fol. 1r-1v. Kummalisel kombel pole nimekirjas Lauagildi 1363. a skraa alguses nimetatud kolme n-ö asutajaliiget. Vt Nottbeck, E. v. Die alten Schragen, 64, 104.

20 TLA, f 191, n 2, s 1, fol. 11r.

21 Eranditeks on vaid 1513/14. a jõulujoodud, mil Suurgildi astus kaks meest rohkem kui Lauagildi; 1523/24. a jõulujoodud, mil Suurgildi astus neli meest rohkem; 1547. a vastlajoodud, mil Lauagildi astus neli meest rohkem, neist kahe nimed aga leiduvad juba ka eelmistel jõulujootudel, ja 1549. a vastlajoodud, mil Suurgildi astus kaks meest rohkem, ent ühe nimi esineb samuti jõulujootudel. TLA, f 191, n 2, s 15, pag. 43, 134, 422, 445; s 1, fol. 57v, 59v, 71r, 72r. 
Seega selgub 16. sajandi esimese poole andmetest, et igaüks, kes astus Suurgildi, astus koheselt ka Lauagildi. Kas sama praktika oli jõus ka 14. ja 15. sajandil, ei saa küll täie kindlusega väita, ent sellele viitab asjaolu, et Lauagildi võeti uusi vendi mitte Lauagildi enda pidustustel (mis vanima skraa kohaselt toimusid teisipäeval pärast ülestõusmispüha ja hingedepäeval), vaid Suurgildi peajootudel. Järgnevalt käsitlengi mõlema gildi liikmeskonda ühtse tervikuna ja peatun nendel isikutel või gruppidel, kes ei ole kaupmehed või kes muul põhjusel üldisest massist silma torkavad.

Esimene üllatav grupp on vaimulikud. 1364. aasta Lauagildi liikmete nimekirjas seisavad esimestena Tallinna piiskop Lodewich (1352-1389) ja Johannes Gotlandilt, kes oli Pühavaimu kiriku vaimulik. ${ }^{22}$ Et nn vaestelaud tegutses Pühavaimu kiriku juures, on selle kiriku esindaja liikmeksolek mõistetav, samuti nagu ka asjaolu, et hiljuti rajatud heategevusliku loomuga gild vajas piiskopi kui kõrgeima kohapealse vaimuliku toetust. Kui Lodewichi ja Johannese puhul võib veel oletada, et tegemist oli gildi (au)liikmetega ${ }^{23}$, kelle toetuse nimel vaadati skraa esimesest punktist (mis nõudis Suurgildi liikmesust) mööda, siis järgmistel sajanditel uute vendade seas esinevate vaimulike kohta see tõenäoliselt paika ei pea. Näiteks 1457. aasta vastlajootudel võeti gildi liikmeks Pühavaimu kirikhärra Ludeke Karwel. ${ }^{24}$ Tema puhul võib kindel olla, et tegemist oli püsiliikme, mitte auliikmega: Karweli nimi esineb 1470. aasta ülestõusmispühade ajal kirja pandud surnud vendade nimekirjas. ${ }^{25}$ Pole välistatud, et Lauagildi ja Pühavaimu kiriku tihedate sidemete tõttu oli teisigi selle kiriku vaimulikke, kes gildi liikmeks astusid. Gildis oli siiski ka teiste kirikute vaimulikke. Näiteks aastail 1509-1521 osales Suurgildi jootudel Albert Westermann noorem, kes oli Niguliste kiriku vikaar. ${ }^{26}$ Lauagildi (resp Suurgildi) liikmeks oli ta astunud 1503. aasta vastlajootudel. ${ }^{27}$ Võib lisada, et vaimulikke on olnud ka Kanuti gildi liikmete seas ${ }^{28}$ Juba see asjaolu näitab, et linna suuremaid gilde ei saa keskajal veel puhtalt ametialasteks organisatsioonideks pidada.

22 TLA, f 191, n 2, s 1, fol. 1r: Int erste Bysschopp Lodewich tho Reuale een her, item her Johan van Godlande. Vt nende kohta: Arbusow, L. Livlands Geistlichkeit vom Ende des 12. bis ins 16. Jahrhundert. Mitau, Steffenhagen, 1904, 55, 119, 285.

23 Erinevalt uusajast ei esine keskaegsetes gildiraamatutes mõistet auliige (auvend). Siin ja edaspidi olen seda mõistet kasutanud tinglikult, et eristada mingis mõttes "ebatavalisi" või ainult korra-paar liikmete nimekirjas esinevaid isikuid gildi "püsiliikmetest". TLA, f 191, n 2, s 1, fol. 25v: her Ludeke Kerwel de kerckher to dem hilgen geste.

25 Samas, fol. $35 \mathrm{v}$.

26 TLA, f 191, n 2, s 15, pag. 7, 110. Alates 1511. aastast esineb ta tiitliga her. Samas, pag. 25. Tema tegevus vikaarina on jälgitav rae arveraamatus aastail 1514-1524. Städtische KämmereiRechnungen 1507-1533. TLA, f 230, n 1, s Ad 32, fol. 58r [nr 3125], 82r [nr 3242], 94v [nr 3305], 106r [nr 3367], 117r [nr 3432], 126r [nr 3487], 136r [nr 3552], 148r [nr 3614], 158r [nr 3673], 168r [nr 3727]. Nurksulgudes numbrid on s Ad 32 sissekannetele antud arveraamatu trükiks ettevalmistamise käigus. Arveraamatut pole veel avaldatud.

27 TLA, f 191, n 2, s 1, fol. 53r.

28 Nt 1534. a vastlajootudel oli üks šafferitest Niguliste kiriku köster Thonius Nyehusen. Alte Nachrichten der St. Kanuti-Gilde 1437-1596. TLA, f 190, n 1, s 60, fol. 105v. 
Uute gildivendade hulgast leiame ka vähemalt seitse linnakirjutajat (Johannes Blomendahl, Christian Czernekow, Reinhold Korner, Otto Manow, Marcus Tirbach, Johann Sulstorp ja Laurentius Schmidt) ${ }^{29}$, kellest kaks kuulus samuti vaimulikuseisusse (Czernekow ja Manow; Czernekowist sai hiljem Tallinna piiskop) ${ }^{30}$ Linnakirjutaja ei olnud küll raeliige, ent õpetatud mehena kuulus ta kahtlemata linna mõjukamate ametnike hulka.

Suurgildist kirjutades on alati rõhutatud, et raehärrasid valiti eranditult selle gildi liikmete hulgast. ${ }^{31}$ See väide peab kahtlemata paika, kui silmas pidada, et käsitööliste gildide liikmed, ammugi veel madalamate elanikkonnakihtide esindajad, raadi ei pääsenud. Küll aga ei pruukinud alati tõele vastata, et kaupmees pidi enne raehärrastaatusesse tõusmist olema Suurgildi liige. Kuidas muidu seletada asjaolu, et uute vendade nimekirjas leidub aeg-ajalt raehärrasid (st et raehärraks saadi enne ja alles siis astuti gildi)? Kui vaadelda Suurgildi arveraamatut, siis vahemikus 1509-1558 esineb selliseid juhtumeid küll kõigest seitsmel korral. ${ }^{32}$ Neile tuleb lisada ka 1547 . aastal vastu võetud rae sündik Jost Clot. ${ }^{33}$ Kui aga vaadelda Lauagildi vendaderaamatu andmeid aastaist 1364-1549, siis ilmneb, et raehärrasid on gildiga liitunud kogu nimetatud ajavahemiku jooksul, kusjuures mõnel joodul koguni paar-kolm korraga. ${ }^{34}$ Kuidas oli võimalik jõuda raehärraseisusesse ilma eelnevalt gildivend olemata, vajab tulevikus veel

29 TLA, f 191, n 2, s 1, fol. 7r (1412, Johens Blomendal des stat schryuer), 51r (1499/1500. a jõulud, mester Karsteianies Sernekow), 55r (Reynoldus Korner), 58r (1514. a vastlad, her Otte Manow), 59r (1521. a vastlad, Markus des rades schryuer), 65v (1536/37. a jõulud, Johann Sulstorp stadt scryffer), 69r (1543/44. a jõulud, Laurens Smydt secretarius). Vt ka s 15, pag. 51 (Manow), 284 (Sulstorp), 378 (Schmidt). Aastad linnakirjutajana: Blomendahl 1405/06-1426, Czernekow 1487-1507 ja 1512-1513, Korner 1507-1512, Manow 1513-1521, Tirbach 1520-1535, Sulstorp 1536-1540, Schmidt 1541-1570. Arbusow, L. Livlands Geistlichkeit vom Ende des 12. bis ins 16. Jahrhundert. Dritter Nachtrag. Mitau, Steffenhagen, 1913, 347-348. Blomendahli täpset ametiaega vt Kala, T. Linnakirjutaja Johannes tor Hove ja hiliskeskaegse Tallinna asjaajamine. Modus vivendi, II. Vana Tallinn, XVI (XX). Toim R. Pullat. Tallinn, Estopol, 2005, 114. Arbusowi järgi oli Manow ametis 1520. aastani, ent teda on kirjutajana nimetatud veel 1521. a septembriski. TLA, f 230, n 1, s Ad 32, fol. 139r [nr 3574].

30 Vt nende kohta Arbusow, L. Livlands Geistlichkeit. Dritter Nachtrag, 131-132, 117-118, 348. Czernekow oli Tallinna piiskop aastatel 1513-1514.

31 Nottbeck, E. v. Die alten Schragen, 13; Johansen, P., Mühlen, H. v. z. Deutsch und Undeutsch, 61, 65; Mühlen, H. v. z. Zur Frühgeschichte der Revaler Gilden, 16; Entsüklopeedia Tallinn, 2. Tallinn, Eesti Entsüklopeediakirjastus, 2004, "Suurgild", 188; Mänd, A. Pidustused, 49.

32 TLA, f 191, n 2, s 15, pag. 55 (her Victor van der Lippe, 1514/15), 59 (her Henninck Passow, 1515), 143 (her Tomes Fegesack, 1524/25), 252 (her Kort Hulsberch, her Johan Figent, 1534), 276 (her Hinrick Hulsberch, 1536). Vt ka s 1, fol. 58r (Lippe), 60r (Fegesack), 64v (K. Hulsberch, Figent), 65v (H. Hulsberch). Neile lisandub 1526/27. a jõuludel vastu võetud her Hinrick Bockholt (s 1, fol. 61r), kes Suurgildi arveraamatus on kirjas ilma tiitlita (s 15, pag. 166). Vt nende kohta Bunge, F. G. v. Die Revaler Rathslinie nebst Geschichte der Rathsverfassung und einem Anhange über Riga und Dorpat. Reval, Kluge, 1874.

33 TLA, f 191, n 2, s 1, fol. 71r (meyster Joest Kloedt smikus dusser stat); s 15, pag. 429 (meyster Jost Kloth).

34 Kolm raehärrat on vastu võetud näiteks 1377. ja 1383. a. TLA, f 191, n 2, s 1, fol. 1v, 2 v. 
lähemat uurimist. Esialgu võiks välja pakkuda oletuse, et mõni neist oli eelnevalt pidanud raehärraametit mõnes teises linnas ja teda veendi Tallinna raadi n-ö üle tulema. Et aga teiste Liivimaa linnade rae koosseisu ja raehärrade ametiaegade kohta on andmed lünklikud, on seda oletust raske kontrollida.

Lisaks Tallinna raehärradele on Suurgildi liikmeks astunud ka teiste Liivimaa linnade raehärrasid, kes jätkasid selles ametis oma kodulinnas. Näiteks Uus-Pärnu raest said Tallinna Suurgildi liikmeks 1516/17. aasta jõulujootudel Asmus Klynt ja 1523. aasta vastlajootudel Johann van Lynthem. ${ }^{35}$ Tartu raehärradest ja bürgermeistritest esinevad Lauagildi uute vendade seas näiteks Evert van den Berge (1429), Hinrick Kulle ning Hinrick Lange (1487/88), Bertold van Elssen (1503) ja Johann Holthusen (1508). ${ }^{36}$ Narva raehärradest astusid gildi näiteks Hermann Happe (1483/84) ja Frederick Korf $(1500 / 01) .{ }^{37}$ Pole teada, kas teiste linnade raehärrad võeti Tallinna gildi auliikmete või püsiliikmetena, ent viimase võimaluse kasuks räägib see, et neid esineb ka surnud vendade nimekirjades. ${ }^{38}$ Kõigis nimetatud linnades oli olemas oma (suur)gild, Tartus sarnaselt Tallinnale ja Riiale ka Lauagild. ${ }^{39}$ Miks pidasid teiste linnade raehärrad vajalikuks (ka) Tallinna gildi liikmeks astuda, - kas oli tegemist puhtalt prestiižiküsimusega või tõusis sellest mingit märgatavat kasu? -, jääb paraku teadmata. Samuti pole andmeid selle kohta, kas Tallinna raehärrasid on liitunud mõne teise linna (suur)gildiga.

Eelnevast selgub, et nagu skraagi lubas, võttis Suurgild oma ridadesse ka mehi, kes polnud Tallinna kodanikud. Viimase tõestuseks lisame veel ühe näite: 1519. aasta vastlajootudel on uute vendade seas üks aadlimees - Acke Vintsens, rüütel

35 TLA, f 191, n 2, s 15, pag. 73 (her Assemys Klynt), 129 (her Johan van Lyntem van der Parnou). Johann van Lynthem valiti Uus-Pärnu raadi 1519. a ning 1523. a sai ta bürgermeistriks. Pärnu linna ajaloo allikad 13.-16. sajandini/Quellen zur Geschichte der Stadt Pernau 13.-16. Jahrhundert. Toim I. Põltsam, A. Vunk. Pärnu, Pärnu Linnavalitsus, 2001, 133, 138. Asmus Klynti (Glindt, Klint) on raehärrana nimetatud 1518. a, hiljem on ta lisaks tegutsenud ka kohtufoogti ja Nikolause kiriku eestseisjana. Samas, 133, 139-140, 146. Bunge järgi on Asmus Klint olnud 1523. a Tallinna raehärra. Bunge, F. G. v. Die Revaler Rathslinie, 108.

36 TLA, f 191, n 2, s 1, fol. 10v (her Euert van den Berghe), 45r (her Hinrick Lange, her Hinrick Kulle), 53r (her Bertold van Elssen), 55v (her Johan Holthusen). Van den Berge kohta vt LUB 7, nr 802; LUB 8, nr 94, 159. Kulle kohta vt LUB 12, nr 800. Lange kohta vt LUB II/1, nr 19, 643, 1065. Van Elsseni kohta vt LUB II/2, nr 403, 510. Temast sai hiljem Tartu toomhärra (esineb allikates skolastikuna 1514-1516). Arbusow, L. Livlands Geistlichkeit, 35-36; Lukas, T. Tartu toomhärrad 1224-1558. Tartu Ülikooli kirjastus, 1998, 61, 266. Holthuseni kohta vt LUB II/2, nr 466, LUB II/3, nr 824, 843.

37 TLA, f 191, n 2, s 1, fol. 42v (her Herman Happe), 51v (Frederick Korf). Korfi nime ees pole siin küll tiitlit her, ent juba kolm kuud hiljem esineb ta allikates raehärrana. LUB II/2, nr 59; vt ka nr 369, 510, 552, 723; LUB II/3, nr 340. Her Frederick Korf osaleb ka Suurgildi 1509/10. a jõulujootudel (TLA, f 191, n 2, s 15, pag. 10). Happe kohta vt LUB II/1, nr 89, 891.

38 Mõnikord on surnud venna nime taha kirja pandud tema kodulinn. TLA, f 191, n 2, s 1, nt fol. 44v (1486, her Hermen Warnynk tor Narwe), 54r (1505, her Jorgen Fickynckhusen borgemester tor Darpte).

39 Tartu Lauagildi on mainitud nt Revaler Regesten, Bd. 3: Testamente Revaler Bürger und Einwohner aus den Jahren 1369 bis 1851 (edaspidi RR 3). Hrsg. R. Seeberg-Elverfeldt. Göttingen, Vandenhoeck \& Ruprecht, 1975, 127. 
Taanist. ${ }^{40}$ Hiljem ei esine tema nimi gildi arveraamatus enam kordagi, mistõttu võib oletada, et teda loeti pigem gildi auliikmeks kui liikmeks. Gild on võõrustanud teisigi kõrgest soost külalisi (näiteks 1507. aastal olid Suurgildil külas Taani kuninga ja Lübecki saadikud ${ }^{41} ; 1524$. aastal oli Lauagildil külas Viljandi komtuur koos "oma junkrute ja tallivendadega" 42 , ent neid pole uute vendade seas kirja pandud.

Kohalike aadlisuguvõsade esindajatele keskaegse Suurgildi ridades on osutanud juba Nottbeck. ${ }^{43}$ Nende hulgas oli ka Remmert von Scharenberg, kellest 1557. aastal sai Suurgildi oldermann (vt tabel 2) ja kelle samanimeline onu oli olnud Tallinna komtuur (1533-1550). ${ }^{44}$ Võib veel lisada, et nii kohalikke kui ka näiteks Taani ja Rootsi aadlimehi on aeg-ajalt osalenud ka Tallinna mustpeade jootudel. $^{45}$

Tallinnas esineb uute gildivendade seas ka arvukalt laevakapteneid ehk kipreid. Näiteks 1545/46. aasta jõulujootudel on neid liikmeks astunud koguni kolmteist. ${ }^{46}$ Laevnikud ja kaupmehed olid ametialaselt tihedalt seotud ja teatavasti oli ka gildi skraas punkt, mis lubas kipreid liikmeks võtta. On raske kindlaks teha, kui palju oli kiprite seas n-ö kohalikke ja kui palju võõramaiseid mehi. Kipreid leiame sageli ka mustpeade jootudel osalejate nimekirjades. ${ }^{47}$ Võimalik, et Tallinna päritolu või Tallinna kaupmeeste teenistuses olevad kaptenid eelistasid liituda Suurgildiga ja võõramaised Mustpeade vennaskonnaga, ent selle kindlakstegemine nõuaks juba omaette uurimistööd.

1536/37. aasta jõulujootudel astus Suurgildi Lambert Glandorp ${ }^{48}$, kes oli elukutselt maalikunstnik ja kelle nimega on seostatud 1561. aastal valminud mustpeade epitaafi. ${ }^{49}$ Maalijaid, puunikerdajaid, klaasijaid ja tislereid ühendav tsunft

40 TLA, f 191, n 2, s 15, pag. 97 (her Acke Vintsens ryttder utt Dennemarcken), 99 (her Acke Vintsenzus ryttder utt Dennemarcken).

41 TLA, f 191, n 2, s 16, pag. 160: ...vor kost vnd wyn do vnse gylde des heren konynges van Dennemarken vnd des stat Lubek sende boden vnd schryuers to gaste hadde in al-9,5 mr $12 \mathrm{~s}$. Tõsi, see külaskäik toimus suvel, mil teatavasti uusi liikmeid vastu ei võetud.

Nottbeck, E. v. Die alten Schragen, 15

44 Mustpeana alustanud Remmertit, kes hiljem jõudis Suurgildi vanema ametini, on mustpeade vendaderaamatus junkruks tituleeritud. Bruderbuch 1500-1581. TLA, f 87, n 1, s 21a, pag. 244, 247. Tallinna kodanikuks sai ta 19. aprillil 1537. Bürgerbuch, 55. Linnakodanik ja Suurgildi liige oli olnud juba ka tema isa Paul, komtuur Remmerti vend. Vt Scharenbergide kohta: Ritterbrüder im livländischen Zweig des Deutschen Ordens. Hrsg. L. Fenske, K. Militzer. Köln, Böhlau, 1993, 567-569.

Mänd, A. Pidustused, 148-149.

TLA, f 191, n 2, s 15, pag. 402; vt ka s 1, fol. 70r.

Mänd, A. Pidustused, 150-151.

TLA, f 191, n 2, s 15, pag. 284; s 1, fol. 65v.

Tegemist on pelga oletusega, sest allikaid, mis Glandorpi autorlust kinnitaksid, pole. Vt Kangropool, R. Tallinna maalijad ja puunikerdajad 1530 - ca 1640. Kataloog. - Kunstiteaduslikke Uurimusi, 7. Toim H. Treier. Tallinn, Kunst, 1994, 117 (viide 4), 118. Pole välistatud, et Glandorpi on epitaafi autoriks peetud just tema tihedate sidemete tõttu kaupmeeskonnaga. Enne Suurgildi astumist kuulus ta Mustpeade vennaskonda, osaledes jootudel 1530/31. a jõuludest 1536. a vastlateni. TLA, f 87, n 1, s 21a, pag. 213, 247. 
kuulus teatavasti Kanuti gildi. Kuidas oli võimalik, et ajal, mil kehtis tsunftisundus, liitus üks maalikunstnik Kanuti gildi asemel Suurgildiga, vajab lähemat uurimist. 17. sajandi puhul ei tekitaks see enam imestust: sel ajal astus mitu maalikunstnikku, eelkõige portretisti, Mustpeade vennaskonna liikmeks ja taotles raelt vabameistri oigusi. ${ }^{50}$ 16. sajandi esimesel poolel oli aga olukord teine: Euroopas hiilgavat karjääri teinud Michel Sittow astus 1506. aastal Kanuti gildi ${ }^{51}$ ja ka portretist Casper Strussist (ka Straus), kes kuulus aastatel 1539-1543 mustpeade hulka ${ }^{52}$ ja kes oli nii tuntud, et isegi Rootsi kuningas Gustav Vasa soovis teda oma teenistusse võtta $^{53}$, sai Kanuti gildi liige. ${ }^{54}$ Tõenäoliselt hakati Tallinnas maalikunsti intellektuaalseks tegevuseks pidama ja portretisti elukutset kõrgelt väärtustama varem, kui seni arvatud. Siiski ei ole praeguse uurimisseisu juures lisaks Glandorpile teada ühtki teist maalikunstnikku, kes oleks vaadeldaval perioodil (st ligikaudu 16. sajandi keskpaigani) Suurgildiga liitunud.

Viimasena peatume naiste liikmeksoleku küsimusel. Nimelt esineb Lauagildi uute liikmete nimekirjades vahemikus 1379-1402 neli naist: raehärra Johann Duderstadti abikaasa Hesse, Oleviste kiriku köstri Martini, Brand Wise (tõenäoliselt kaupmees) ja raehärra Johann Lore abikaasa. ${ }^{55}$ Hiljem pole naisi ei Lauagildi ega ka Suurgildi uute liikmete seas enam nimetatud. Suurgildi skraas räägitakse valdavalt gildivendadest, ent paaris sättes esineb ka väljend "vennad ja õed". Näiteks maksti Niguliste kirikhärrale surnud vendade ja õdede heaks peetavate hingemissade eest ja mõne gildiliikme surres pidid matustele tulema kõik linnas viibivad vennad ja õed. ${ }^{56}$ Järelikult luges Suurgild oma liikmete hulka ka gildi-

50 Ehasalu, P. Maalijad Tallinna Mustpeade Vennaskonnas, vabameistrid ja kunstnike eneseteadvuse tõus 17. sajandil. - Renovatum Anno, 1995, [1]-[3].

51 Mänd, A. Michel Sittow and Reval (Tallinn): a new look at records in the Tallinn City Archives. Michel Sittow 1469-1525. The Artist Connecting Estonia with the Southern Netherlands. Toim T. Abel. Tallinn, Eesti Kunstimuuseum, 2001, 7.

52 TLA, f 87, n 1, s 21a, pag. 273, 281, 284 (siin ekslikult Jasper), 296, 298, 306. Varem arvasin, et Casper Struss, keda on 1540. a vastla- ja jõulujootudel tituleeritud conterfeiter' iks (st portretistiks), osales mustpeade jootudel vaid külalisena (Mänd, A. Pidustused, 153), ent nüüd olen veendunud, et kunstnikud ja õpetatud mehed olid juba 16. sajandil vennaskonna liikmed.

53 Kangropool, R. Tallinna maalijad, 119.

54 Strussi Kanuti gildi astumise aasta pole teada, tõenäoliselt toimus see 1543. a paiku, mil tast sai kodanik. 1547. a vastlajootudel oli ta üks šafferitest (Casperi asemel on ekslikult kirjas Jasper Strus) ja 1551/52. a jõuludest kuni 1552/53. a jõuludeni oli ta gildi kaasistuja. TLA, f 190, n 1, s 60, II, fol. $17 \mathrm{v}, 24 \mathrm{r}, 25 \mathrm{r}$.

55 TLA, f 191, n 2, s 1, fol. 2r (vrouwe Hesse Duderstadesche), 3v (Mertyns wyff des costers van sunte Olaue, Brand Wysen wyff), 5v (her Johan Loren wyff). Meeste kohta vt Bunge, F. G. v. Die Revaler Rathslinie (Duderstadt, Lore); RR 3, nr 4 (Duderstadti testament); Arbusow, L. Livlands Geistlichkeit. Dritter Nachtrag, 341 (Oleviste kiriku Martinus). Brand Wise esineb korduvalt teises ja kolmandas pärandiraamatus: Das zweitälteste Erbebuch der Stadt Reval (1360-1383). Hrsg. E. v. Nottbeck. Reval, Kluge, 1890; Das drittälteste Erbebuch der Stadt Reval (1383-1458). Hrsg. E. v. Nottbeck. Reval, Kluge, 1892.

56 Nottbeck, E. v. Die alten Schragen, $43, \S 31,44$, § 35. Surnud vendade ja õdede heaks tellitud missade ja palvuste eest tasumist nimetatakse regulaarselt ka oldermanniraamatus. TLA, f 191, n 2, s 16 , passim. 
vendade naisi ja nende leski. Siiski ei olnud nende seisund vendadega võrdväärne: naisi ei valitud eales ühelegi ametipostile, nad ei osalenud üldkoosolekul ja isegi jootude ajal kutsuti neid gildimajja külla vaid teatud päevadel. ${ }^{57}$

Suurgildi ja Lauagildi raamatutes esineb tuhandeid nimesid ja kõiki neid polnud võimalik selle artikli jaoks läbi töötada. Siiski piisab ka eespool toodud näidetest, et tõdeda: kuigi kaupmehed moodustasid Suurgildi liikmeskonna enamiku, ei saa seda siiski ainult kaupmeeste gildiks pidada. Ka ei olnud kõik liikmed Tallinna kodanikud.

\section{KAUPMEHE SOTSIAALNE KARJÄÄR}

Kaupmeeste sotsiaalne karjäär sai enamasti alguse Mustpeade vennaskonnas ja jätkus Suurgildis. Mustpeade vennaskonna tuumiku moodustasid teatavasti vallalised kaupmehed ja kaupmehesellid. Üleminek ühest korporatsioonist teise oli traditsiooniliselt seotud selliste tähtsate sündmustega nagu abiellumine ja kodanikuks saamine.

Esimesed teadaolevad ettekirjutused selle kohta, et mustpeast peab abielludes saama Suurgildi liige, pärinevad 16. sajandi esimesest poolest. Näiteks Tartu Suurgildi 1509. aasta määruses on kirjas, et kui mustpea võtab naise, peab temast järgmiste jootude ajal saama gildi liige. ${ }^{58}$ Tallinna Suurgild otsustas 1540 . aasta paiku, et ühestki mustpeast ei või saada gildivend enne abiellumist. ${ }^{59} 1543$. aastal on jällegi nõutud, et esmakordselt abielluja peab astuma gildivennaks enne pulmi. ${ }^{60}$ Ükskõik kumb protseduur ka enne aset leidis, igal juhul olid abiellumine ja gildiga liitumine omavahel tihedalt seotud.

Tihedalt seotud olid ka kodanikuks saamine ja gildi astumine. Kui võrrelda omavahel mustpeade jootudel osalejate nimekirju, uute gildivendade nimekirju ja Tallinna kodanikeraamatu andmeid, selgub, et harilikult anti kodanikuvanne mõni kuu enne Suurgildi astumist. Mõistagi esines ka erandeid, neid vaatleme lähemalt allpool.

Oli ka mustpäid, kellest ei saanud iialgi Suurgildi liiget, ja mitte iga Suurgildi liige polnud varem kuulunud Mustpeade vennaskonda. Lisaks on teada, et ka mustpeade seas oli mõni abielumees ja Suurgildi liikmete seas poissmehi. ${ }^{61}$ Laias laastus toimus vahetegemine siiski perekonnaseisu, kodakondsuse ja selli-meistri kriteeriumi alusel. Seda näitab ka asjaolu, et mustpäid tavatseti dokumentides nimetada sellideks (geselle), Suurgildi liikmeid aga kodanikeks (borgere).

57 Vt Mänd, A. Pidustused, 88, lisa 5, 479-483. Vrd 91-92, 113, 352-353.

58 Mettig, C. Der Schragen der Grossen Gilde zu Dorpat aus dem 14. Jahrhundert in hochdeutscher Übersetzung. Riga, Häcker, 1909, 15-16, § 6. Vt ka LUB II/3, nr 511, § 6.

59 Schreiben über den Eintritt von Schwarzenhäupterbrüder in die Grosse Gilde (1540). TLA, f 87 , n 1 , s 102 , fol. 1 r.

60 Nottbeck, E. v. Die alten Schragen, 62, § 98, 91, § 98 (1543).

61 Amelung, F., Wrangell, G. Geschichte der Revaler Schwarzenhäupter. Reval, Wassermann, 1930, 49-50, 56-59. 
16. sajandi esimesel poolel teravnes Suurgildi ja Mustpeade vennaskonna vaheline rivaalitsemine ja mõlemad tegid pingutusi, et endale rohkem liikmeid võita. Sellega on seletatav ka mustpeade 1540. aasta korraldus, kus on öeldud, et kui mustpeast saab kodanik, võib ta sellest hoolimata vennaskonda edasi jääda. ${ }^{62}$ Suurgildi skraa 1542. aasta täienduses on kirjas, et liikmeks saamist võivad taotleda nii kodanikud kui ka sellid, tingimuseks on vaid sünnikirja olemasolu. ${ }^{63}$ Mustpeade vennaskonnas olevaid kodanikke keelas Suurgild võtta pruulijate kompanii liikmeteks ja seega polnud neil ka õigust õlut müügiks pruulida. ${ }^{64}$ Samal ajal viitavad need korraldused jällegi sellele, et reeglina ei olnud mustpead kodanikud ja Suurgildi liikmed olid.

Nagu olen varemgi väitnud, oli ühe kaupmehe tüüpiline sotsiaalne karjäär kokkuvõtvalt järgmine: alates 18. eluaastast (st täisealiseks saades) astus ta Mustpeade vennaskonda, kuhu jäi kuni abiellumiseni, ja seejärel siirdus edasi Suurgildi, kuhu jäi surmani. Kõrgeim ühiskondlik positsioon, mille poole püüelda, oli raehärra- või koguni bürgermeistriamet. ${ }^{65}$ Öeldu peegeldab siiski vaid enam levinud, seega üldisi tendentse ühe kaupmehe elus. Kui süveneda allikatesse, ilmneb, et sellel mudelil oli küllalt palju erandeid. Järgnevalt vaatleme nii "tavapärast" kui ka "erandlikku" käitumist juba konkreetsete näidete põhjal.

Tabelist 1 leiame lühikokkuvõtte mõne 15. sajandi lõpul ja 16. sajandi esimesel poolel tegutsenud kaupmehe sotsiaalsest karjäärist. Tabeli jaoks välja valitud kaupmehed kuulusid sotsiaalse positsiooni mõttes edukate hulka, st nende hulka, kelle kätte oli Suurgildis koondunud võim ja prestiiž: kõik nad jõudsid oldermanni või vähemalt kaasistuja ametipostini. Veelgi enam, paljudest said hiljem raehärrad, mis tähendas ühe kaupmehe jaoks sotsiaalse karjääri tippu.

Ent alustagem nende sotsiaalse karjääri algusaastaist, st seotusest Mustpeade vennaskonnaga. Nii tabeli andmed kui ka mustpeade jootudel osalejate nimekirjad tõendavad, et keskeltläbi veetis üks kohalik kaupmehesell vennaskonnas viis aastat. Muidugi esines ka erandeid. Oli rida mustpäid, kes jäid vennaskonnaga seotuks vaid üheainsa pidustuse jooksul (tabel 1: Hans Hower, Bertold Kulle). Teisest küljest oli ka mehi, kes nautisid vallaliste seltskonda kümmekond aastat (Rotger Boismann, Hans Peppersack) või kauemgi (nt Bernt Bussmann 16 aastat). Kui tuli aeg Mustpeade vennaskonnast lahkuda, liituti Suurgildiga enamasti järgmise peajoodu ajal. Võimalik oli aga ka selline stsenaarium, et pidutsedes viimast korda koos mustpeadega, astuti Suurgildi liikmeks juba samade jootude ajal (tabelis $1 \mathrm{nt}$ Victor Bretholt, Hans Eckholt, Jurgen Gellinckhusen). See oli täiesti võimalik, sest üldkoosolek, mille käigus Suurgild uusi vendi vastu võttis, toimus kahenädalaste jootude lõpupäevil. Mõned mehed, kes liitusid gildiga kirjeldatud stsenaariumi järgi, on viimastel jootudel Mustpeade vennaskonnas maksnud ainult

\footnotetext{
Samas, 57.

Nottbeck, E. v. Die alten Schragen, 61, § 95.

Samas, 58, § 70 .

65 Mänd, A. Pidustused, 56.
} 
poole osavõtumaksust. ${ }^{66}$ Võimalik, et põhjuseks oli soov kulusid kokku hoida, sest Suurgildi astudes tuli uutel vendadel maksta nii jootudest osavõtu maks kui ka spetsiaalne sisseastumismaks. ${ }^{67}$

Ei ole võimalik kindlaks teha, kas Suurgildi üleminek oli praktikas alati abiellumisega seotud: meil lihtsalt pole allikaid, mille põhjal saaks abiellumise aega tuvastada. Küll aga on võimalik omavahel võrrelda kodanikuvande andmise ja gildi astumise aega. Üllataval kombel ilmneb, et kuigi Suurgildi liikmeid tituleeritakse allikais kodanikeks, ei pruukinud nad gildi liikmeks saades veel sugugi kodanikud olla. Toome näiteid jällegi tabelist 1. Tõsi, seal on mitu meest, kes tõepoolest andsid kodanikuvande mõni kuu enne Suurgildi liikmeks saamist (Kort Beckhusen, Bernt Bussmann, Gert Kampferbeck, Hans Kock). Nende kõrval oli aga ka neid, kes astusid enne gildi ja alles siis said kodanikeks. Mõnikord võis see vahemik venida kaunis pikaks, näiteks Kort Kardenal andis kodanikuvande neli aastat ja Gert Hulshorst koguni seitse aastat pärast gildivennaks saamist (tabel 1). Mõnede meeste puhul ei ole nende kodanikuks saamise aega võimalik kindlaks teha, sest kodanikeraamatu andmed ei ole kõigi aastate osas täielikud. $^{68}$

Kahe tabelis esineva mehe puhul on aga "tavapärasest" kõrvalekaldumine silmatorkavalt suur. Esimene neist, Saaremaalt pärit Bertold Kulle (Oziliensis), sai Tallinna kodanikuks 1508. aastal, seega ammu enne seda, kui ta ilmub mustpeade nimekirjadesse (1515) ja astub Suurgildi (1517). Vastupidine näide on Hans Westhoff, kes paistab olevat andnud kodanikuvande kakskümmend aastat pärast seda, kui temast sai gildivend (tabel 1). Muidugi ei ole kummagi puhul välistatud, et allikates esineb kaks samanimelist meest, näiteks isa ja poeg, ent seni ei ole mul õnnestunud teise Bertold Kulle või Hans Westhoffi olemasolu tuvastada.

Enne kui analüüsida kaupmeeste karjääri Suurgildis, tasub lühidalt meelde tuletada, milliseid ametimehi gildi juhtimiseks ja igapäevaseks asjaajamiseks vajati. Gildi eesotsas seisis gildivanem ehk oldermann, keda abistasid kaks tema lähimat nõuandjat, keda nimetati kaasistujateks (bisitter). Endised oldermannid ja kaasistujad moodustasid gildi vanematekogu. Võimalik, et lisaks neile kuulusid vanemate hulka ka need eakad gildivennad, kes polnud juhtiva ametini jõudnud. Liikmete jagunemine n-ö vanemateks ja nooremateks on allikates täheldatav alates 16. sajandi esimesest poolest. ${ }^{69}$ Lisaks gildi juhtkonnale valiti liikmete seast ka teisi ametimehi. Aasta peamiste pidustuste ja igapäevase seltsielu korraldamise eest vastutasid šafferid (peajootude šafferid kannavad allikates nimetust gerdelude, pennijootude omad schaffere).$^{70}$ Hoone korrashoiu ja laiemalt majandusküsimus-

\footnotetext{
66 Nt Hans Frilinck 1526/27. a jõulujootudel. TLA, f 87, n 1, s 21a, pag. 185.

67 Mänd, A. Pidustused, 312.

68 Das Revaler Bürgerbuch 1409-1624 (edaspidi Bürgerbuch). Hrsg. O. Greiffenhagen. (Publikationen aus dem Revaler Stadtarchiv, 6.) Tallinn, 1932, XI.

69 Nottbeck, E. v. Die alten Schragen, 18, 57, § 61, § 64, 62, § 96.

70 Vt šafferite ülesannete kohta Mänd, A. Pidustused, 15-16.
} 
tega tegeles gildimaja eestseisja (vormunder või vorstender des gildestouen), keda alates 1500. aastast on hakatud nimetama ehitusmeistriks (bumester).$^{71}$ Lisaks jagas gild oma liikmetele veel mitmesuguseid ülesandeid, mis olid seotud konkreetse valdkonna või mõne sündmusega (näiteks eestantsijaamet pidustustel), ent neid pole peetud nii tähtsaiks kui eelnimetatuid ja nende täitjaid ei ole gildi raamatutesse kirja pandud.

Suurgildi dokumendid tõendavad, et nooremaid liikmeid nimetati enamasti ameteisse, mis panid proovile nende organiseerimisvõimed ja füüsilise vastupidavuse: peajootude ja pennišafferid, samuti eestantsijad. Alles siis, kui gildivenna "staaž" ulatus vähemalt kümne aastani, võis ta hakata kandideerima kaasistuja ametikohale. Selleks et saada gildi oldermanniks, pidi gildis olema olnud vähemalt tosin aastat, aga nagu praktika näitab, oli see periood enamasti pikem, ulatudes tavaliselt paarikümne aastani (tabel 2). Kui süveneda tabelis 2 esitatud 16. sajandi esimesel poolel gildi juhtinud oldermannide nimekirja, näeme, et nende hulgas on neli meest, kellel see "ooteaeg" kujunes veelgi pikemaks - 26 või 27 aastat. Tõenäoliselt ei piisanud oldermanniks saamiseks üksnes kõrgest east, vaid pidi olema ka administratiivselt võimekas ja kaasvendade poolt tunnustatud isik, ent siiski oli vanus keskaegses ühiskonnas üks tähtsamatest võimu ja prestiiži eeltingimustest.

Sama põhimõte, st et oldermanniks valiti vanu ja mõjukaid gildiliikmeid, selgub ka Kanuti gildi arveraamatust. ${ }^{72}$ Küll aga torkab kahe gildi andmeid võrreldes silma üks väike erinevus: kui Kanuti gildis oli praktiliselt iga oldermann pidanud varem kaasistujaametit ${ }^{73}$, siis Suurgildi puhul see alati nii ei olnud. Ka tabelis 1 näeme kolme meest (Gert Kampferbeck, Hans Kock, Hans Westhoff), kes on valitud oldermanniks sellest hoolimata, et nad polnud kunagi kaasistujaametit pidanud. Ilmselt oli Suurgildis võimalus tõestada oma administratiivset võimekust ka teistes ametites, näiteks Hans Kock ja Gert Kampferbeck olid varem täitnud Lauagildi eestseisja vastutusrikast ülesannet (esimene 1520., teine 1556. aastal). ${ }^{74}$

Oldermanni ametiaja pikkuseks oli kolm, kaasistujal kaks aastat. Uus oldermann valiti traditsiooniliselt vastlajootude lõpul toimuval suurel üldkoosolekul (in der groten stevene), seevastu kaasistuja võis vahetuda ka jõulujootude lõpul. Uusi kaasistujaid ei valitud kunagi korraga, mistõttu uus oldermann "päris" vähemalt ühe kaasistuja eelmiselt oldermannilt. Sama tava kehtis ka Kanuti gildis. Tõenäoliselt pidi selline süsteem tagama võimu ja kogemuste sujuvama ülemineku ühelt juhatuselt teisele.

71 TLA, f 191, n 2, s 16, vrd pag. 139 (1496, vormunder), 142 (1498, vorstender) ja 145 (1500, boumester).

72 Mänd, A. Tallinna Kanuti gild, 139-141.

73 Samas, 144.

74 TLA, f 191, n 2, s 1, fol. 58v (Kock); s 3, fol. 22v (Kock), 192v (Kampferbeck). 
Tabeli 1 põhjal näeme, et mõnikord jäi ametiaeg eeldatust lühemaks, seda eriti kaasistujate puhul. Kuna selle põhjusi ei ole gildi raamatutesse enamasti kirja pandud, võib vaid oletada, et vahele võisid tulla näiteks pikem välisreis või haigus. Ametiaega võis katkestada aga ka edutamine, kui kasutada tänapäeva terminit. Näiteks Victor Bretholt sai kaasistujana tegutseda vaid ühe peajoodu ajal, sest juba samade pidustuste lõppedes valiti ta gildi oldermanniks (tabel 1). Mathias Depholt, kes sai oldermanniks 1494. aasta vastlajootude lõpul, valiti kaks aastat hiljem raadi. ${ }^{75}$ Sama juhtus vaevalt aasta ametis olnud Hans Kockiga 1521. aastal, mil ta "transformeerus" her Johan Kockiks, mistõttu gild pidi uue oldermanni valimised korraldama ebatraditsioonilisel ajal, nimelt nelipühade paiku. ${ }^{76}$ Muidugi tuli ka ette, et oldermanni ametiaeg lühenes surma tõttu. Näiteks 1464. ja 1465. aastal, kui linnas möllas katkuepideemia, suri aasta jooksul järjest kaks oldermanni - Segebode Swan ja Detert Gelpin - ja gildil ei jäänud muud üle, kui kutsuda tagasi enne Swani ametis olnud Hans Kortsack, kes võttis gildi juhtimise kuni järgmiste vastlajootudeni enda peale. ${ }^{77}$

Et tabelis 1 oli võimalik edastada vaid piiratud arv sündmusi ja tegevusi, kirjeldagem paari kaupmehe sotsiaalset karjääri lähemalt. Albert Westermann vanem esineb mustpeade jootude nimekirjas vaid korra, 1476/77. aasta jõulujootudel. ${ }^{78}$ Samade jootude ajal astus ta ka Suurgildi ja pisut vähem kui poole aasta pärast, 5. mail 1477, andis kodanikuvande. ${ }^{79}$ Noore gildivennana tuli tal 1478/79. aasta jõulujootudel täita šafferi kohuseid. ${ }^{80}$ Kaalukamad ülesanded langesid talle osaks sajandi viimasel kümnendil: 1490. aastal oli ta Lauagildi eestseisja, 1492/93. aasta jõulujootudel sai temast Suurgildi kaasistuja ja 1499. aasta vastlajootude lõpul oldermann (tabel 1). ${ }^{81}$ Oldermanniamet, mida ta pidas 1502 . aasta vastlajootudeni, jäi ka tema karjääri tipuks, sest raadi teda ei valitud. Suurgildi jootudel osales Albert Westermann viimast korda 1523 . aasta vastlatel ja 1524 . aastal ta suri. ${ }^{82}$

Eelnev ei kajasta sugugi kõiki Albert Westermanni ühiskondlikke kohustusi. Näiteks on ta pärast oldermanniameti lõppemist tegutsenud ka kirikusfääris: aastatel 1502-1507 on raad maksnud talle Niguliste kiriku Blasiuse altaril teenimise (?) eest aastas 6 marka vikaaritasu. ${ }^{83}$ Patronaadiõigus selle altari üle kuulus

\footnotetext{
TLA, f 191, n 2, s 16, pag. 142.

Samas, pag. 198.

TLA, f 191, n 2, s 1, fol. 30v.

Bruderbuch 1446-1499. TLA, f 87, n 1, s 20, pag. 208.

TLA, f 191, n 2, s 1, fol. 39r; Bürgerbuch, 32.

TLA, f 191, n 2, s 16, pag. 111.

TLA, f 191, n 2, s 1, fol. 46r; s 16, pag. 135, 145.

TLA, f 191, n 2, s 15, pag. 128; n 2, s 3, fol. 37v. Pole välistatud, et Westermann suri juba 1523. a, sest surnud vennad on kirja pandud 1524. a esimesel poolel ja hõlmavad aasta jooksul surnuid.

83 Kämmereibuch der Stadt Reval 1463-1507 (edaspidi KB 1463-1507). Hrsg. R. Vogelsang. (Quellen und Darstellungen zur Hansischen Geschichte, 27, 1-2.) Köln, Böhlau, 1983, nr 2575, 2618, 1654, 2689, 2723; TLA, f 230, n 1, s Ad 32, fol. 2r [nr 2756].
} 
Suurgildile. ${ }^{84}$ Edaspidi maksti seda tasu Westermanni poegadele, kes otsustasid juba noorest peast vaimulikukarjääri kasuks: algul her Antonius Westermann, pärast viimase surma her Albert Westermann noorem. ${ }^{85}$ See, et raad maksis ühele kaupmehele vikaaritasu, polnudki nii väga erakordne - lisaks Albert Westermann vanemale on see teada ka teiste meeste puhul (nt Israhel van Mer, Ewert Hessels). ${ }^{86}$ Kas see viitab sellele, et kaupmees võis tõepoolest ka vaimulikuna tegutseda või on need maksed kuidagi teisiti tõlgendatavad, vajab tulevikus lähemat uurimist.

Ei tohi unustada, et kõiki eelnimetatud ameteid või ülesandeid täitis Westermann oma kaupmehekarjääri kõrvalt. Tema äril, partneritel ja ärisidemetel me selles artiklis ei peatu. Pigem oli eesmärgiks näidata, milliseid ühiskondlikke tegevusi aktiivne ja mõjukas linnakodanik oma põhitegevuse kõrvalt veel täitis ja millised on neid tegevusi peegeldavad allikad. Kui Albert Westermann oli kaupmees, kelle tegusaimad aastad jäid 15. sajandi lõpukümnendeisse, siis nende meeste kohta, kes elasid 16. sajandi esimesel poolel, on tänu säilinud allikate suurenenud hulgale veelgi rohkem andmeid.

Victor Bretholt, bürgermeister Marquart (III) Bretholti poeg ${ }^{87}$, astus Mustpeade vennaskonda $1524 / 25$. aasta jõulujootudel ja jäi sinna neljaks aastaks. ${ }^{88}$ Victor paistab olevat olnud erakordselt tegus mees, sest peaaegu iga joodu ajal on talle usaldatud mõni vastutusrikas ülesanne: $1524 / 25$. aasta jõulujootudel oli ta tõrvikutantsija, 1525/26. aasta jõulujootudel Niguliste kihelkonna naiste peolekutsuja, 1526/27. aasta jõulujootudel neidude tantsitaja, 1527. aasta vastlajootudel eestantsija raekojas ja 1527/28. aasta jõulujootudel jällegi Niguliste kihelkonna naiste peolekutsuja. ${ }^{89}$ Loetletud ametid osutavad Victori heale tantsuoskusele ja tõenäolisele menule õrnema soo hulgas. 1528/29. aasta jõulujootudel pidutses ta viimast

84 Tegemist oli Püha Blasiuse, Viktori ja Jüri auks pühitsetud altariga. Vt selle altari kohta lähemalt Mänd, A. Püha Viktor - Tallinna kaitsepühak? - Kunstiteaduslikke Uurimusi, 2003, 3-4 [12], 22-23.

85 Antonius Westermann sai Blasiuse altaril teenimise eest tasu aastatel 1508-1512 (s Ad 32, fol. 8v [nr 2798], 39r [nr 3012]). Võimalik, et ta oli sellele kohale määratud juba 1506, sest sel aastal on Albert Westermann saanud tasu oma poja asemel (KB 1463-1507, nr 2723). 1513. a märtsiks on Antonius surnud ja tasu saab jällegi isa (s Ad 32, fol. 46r [nr 3058]). Albert Westermann noorem teenis altaril aastail 1514-1524 (s Ad 32, fol. 58r [nr 3125], 168r [nr 3727]). Mõlemal oli ilmselt magistrikraad, sest neid tituleeritakse allikates kord her'iks, kord mester'iks.

86 Kaupmees ja raehärra $(1485,1495)$ Israhel van Mer sai aastail 1493-1495 tasu hommikumissa eest Oleviste kirikus (KB 1463-1507, nr 2209, 2290). Vt tema kohta tabel 1. Kaupmees ja raehärra (1507-1524) Ewert Hessels sai sama missa eest tasu aastail 1519-1524 (TLA, f 230, n 1, s Ad 32, fol. 117r [nr 3432], 168r [nr 3727]). Vt tema kohta Mänd, A. Pidustused, 231.

87 Perekond Bretholti kohta vt Karnatz, H. Zwischen der Bai und Nowgorod: Versuch einer Stammfolge der hansischen Kaufmannsfamilie Bretholt. - Ostdeutsche Familienkunde, 1974, Jg. 22, Heft 2, 33-41. Victor sündis Marquarti teisest abielust, tema ema oli Catharina von der Heyde. Samas, 36, 38-39. TLA, f 87, n 1, s 21a, pag. 164, 198.

89 Bruderbuch 1500-1570. TLA, f 87, n 1, s 21, fol. 150v, 152r, 154r, 155r, 156r. Vt ka Mänd, A. Pidustused, 146. 
korda koos mustpeadega, makstes täisosavõtumaksu, ja astus jootude lõpul Suurgildi. ${ }^{90}$ Kas tänu suguvõsa tuntusele või siis kodanikeraamatu ebatäielikkuse tõttu ei leia me viimasest ei Victori ega ka tema vendade kodanikuks saamise aastat. ${ }^{91}$

Victori aktiivsus ei raugenud ka Suurgildis. 1530. aastal oli ta šafferiks maikrahvipeol ja 1537. aastal vastlajootudel. ${ }^{92}$ 1539. aastal oli ta pennišaffer õue $e^{93}$ jooksul, mis jäi jõulu- ja vastlajootude vahele, ja 1542. aastal täitis ta sama ülesannet vastlate ning ülestõusmispühade vahelise õue jooksul. ${ }^{94} 1545$. aastal oli ta Lauagildi eestseisja. ${ }^{95}$ 1547. aasta vastlajootudel täitis ta Suurgildi kaasistuja kohuseid, ent valiti juba samade jootude lõppedes oldermanniks. ${ }^{96}$ Erinevalt oma poolvennast Marquart IV-st ja vennast Jasperist temast raehärrat siiski ei saanud. Suurgildi jootudel osales ta viimast korda 1557 . aasta vastlatel.${ }^{97}$ Victori surmaaastat pole õnnestunud välja selgitada, ent veel 1. märtsil 1558 on ta vandunud truudust ordumeister Wilhelm Fürstenbergile. ${ }^{98}$ Surnuna on teda nimetatud 1571. aastal, ent tegelik surmaaeg ei selgu sellestki dokumendist. ${ }^{99}$

Nii Albert Westermann kui ka Victor Bretholt on heaks näiteks edukast ja sotsiaalselt aktiivsest linnakodanikust. Mõlemad saavutasid enamat kui n-ö keskmine kaupmees, jõudes Suurgildis juhtivale positsioonile. Samas ei kuulunud nad ka linnaeliidi tippu, sest kumbagi ei valitud raadi.

Nagu juba eespool rõhutatud, oli vanus tähtsaks eeltingimuseks kõrgele ametikohale jõudmisel. Allikad tõendavad, et ka raehärrasid valiti eakamate gildivendade hulgast, enamasti nende seast, kes olid gildis pidanud kas oldermannivõi kaasistujaametit, st tõendanud oma administratiivset võimekust (tabel 1). Kuigi raehärrad jäid Suurgildi liikmeteks ka pärast raadi üleminekut, tõmbusid nad arusaadavalt aktiivsest gildielust tagasi. Rael olid ka oma korporatiivsed pidustused, mida peeti valdavalt raekojas. Suurgildi külastas raad peajootude, st jõulude ja vastlate ajal ainult teatud kindlal päeval. ${ }^{100}$ Kas neil eelkirjeldatud juhtudel, kui raehärra astus Suurgildi liikmeks, pidutses ta vastavate jootude ajal Suurgildi majas või ilmus sinna ainult vastuvõtutseremoonia ajaks, on teadmata. Küll aga on gildi jootudel osalenud ja täisosavõtumaksu maksnud üksikud teiste

90 TLA, f 87, n 1, s 21a, pag. 198; f 191, n 2, s 15, pag. 185.

91

Victor (nagu ka tema vend Jasper) esineb kodanikeraamatus küll korduvalt, ent seda seoses truudusevannetega erinevatele isandatele.

92 TLA, f 191, n 2, s 19, pag. 18; s 15, pag. 286.

93 Nii mustpeade kui ka Suurgildi seltsieluline aasta jagunes seitsmeks nn õueks (Hof), mille piirtärminiteks olid aasta olulisemad pühad. Vt selle kohta Mänd, A. Pidustused, 71.

94 TLA, f 191, n 2, s 20, fol. 10r, 13v.

95 TLA, f 191, n 2, s 1, fol. 70r; n 2, s 3, fol. 123v.

96 TLA, f 191, n 2, s 15, pag. 421, 427.

97 TLA, f 191, n 2, s 15, pag. 525. (1558-1559. a sõja tõttu joote ei peetud, 1560. a vastlajootudel tema nime enam teiste seas ei ole.)

98 Bürgerbuch, 71 .

99 Karnatz, H. Zwischen der Bai und Nowgorod, 38.

100 Mänd, A. Pidustused, 88, vt ka 479-483 (lisa 5). 
linnade raehärrad. ${ }^{101}$ Aeg-ajalt kohtab mõnd raehärrat ka mustpeade jootudel. ${ }^{102}$ Selline käitumine on siiski olnud erandlik, sest valdavalt pidutseti ikkagi koos oma korporatsiooniga.

Need endised oldermannid, keda raadi ei valitud, täiendasid gildi vanematekogu ridu. Endised oldermannid ja teised gildi vanemliikmed on jootudest osavõtjate nimekirjades üles tähendatud esimestena. ${ }^{103}$ Vanematel oli gildiasjade üle otsustamisel tunduvalt rohkem võimu kui noorematel gildivendadel, samuti sai neile osaks mitmeid privileege. Üheks selliseks võib lugeda ka peajootude käigus toimunud pidulikku söömaaega, mis oli mõeldud ainult gildi oldermannile ja vanematele. ${ }^{104}$ Need on jällegi heaks näiteks selle kohta, et gildi liikmed polnud võrdsed, vaid et eksisteeris tugev gildisisene hierarhia.

\section{KOKKUVÕTE}

Suurgildi liikmeskonna analüüs näitab, et senises ajalookirjanduses leiduv määratlus korporatsioonist kui linnakodanikest kaupmeeste gildist ei pea täielikult paika: gildi liikmeskond oli palju mitmekesisem, hõlmates lisaks kaupmeestele ka üksikuid vaimulikke, linnaametnikke, aadlikke, kipreid ja kunstnikke, aga ka näiteks teiste linnade raehärrasid. Siiski oli valdavalt tegemist sotsiaalselt lähedase positsiooniga inimestega. Sugugi kõik gildivennad polnud Tallinna kodanikud: kodanikuvannet võidi anda aastaid pärast gildi astumist, samuti oli liikmete seas teiste linnade kodanikke. Gildi liikmeteks loeti ka naisi, ehkki nende õigused olid meestega võrreldes piiratud.

Uurides kaupmeeste sotsiaalset karjäri, nende üleminekut ühest korporatsioonist teise ja korporatsioonisiseseid ameteid, oli võimalik välja tuua nii enamlevinud ehk tavapärast käitumist kui ka "normist" kõrvalekaldumisi. Loodetavasti aitab see kaasa keskaja ühiskonnas valitsenud sotsiaalse hierarhia ja käitumismudelite paremale mõistmisele.

\section{TÄNUAVALDUS}

Uurimus on valminud Eesti Teadusfondi toetusel (grant nr 5401).

\footnotetext{
101 Nt Narva raehärra Henninck Passow pidutses Suurgildis aastail 1515-1516. TLA, f 191, n 2, s 15, pag. 63, 68 .

102 TLA, f 87, n 1, s 20, pag. 127 (her Reynold van Werden), 242 (her Tymen Rapes), 286 (her Johan Bar), 298 (Bar). Vt nende kohta Bunge, F. G. v. Die Revaler Rathslinie.

103 TLA, f 191, n 2, s 15, pag. 307, 313, 320 jm.

104 Mänd, A. Pidustused, 89, 334.
} 
Tabel 1. Näiteid kaupmeeste sotsiaalsest karjäärist hiliskeskaegses Tallinnas ${ }^{105}$

\begin{tabular}{|c|c|c|c|c|c|c|c|}
\hline Nimi & MP liige & $\begin{array}{l}\text { Kodanik } \\
\text { alates }\end{array}$ & $\begin{array}{c}\text { SG liige } \\
\text { alates }\end{array}$ & SG kaasistuja & $\begin{array}{c}\mathrm{SG} \\
\text { oldermann }\end{array}$ & Raehärra & Surnud \\
\hline Kort Beckhusen & $\begin{array}{l}1523 \mathrm{v}- \\
1528 \mathrm{v}\end{array}$ & 24.10 .1528 & $1528 \mathrm{j}$ & $1541 \mathrm{v}-1542 \mathrm{j}$ & & & $1546 ?$ \\
\hline Hinrick & $1513 \mathrm{v}-$ & & $1518 \mathrm{j}$ & $1534 \mathrm{v}-1535 \mathrm{j}$, & $1541-1544$ & $1554-1563$ & $1563 ?$ \\
\hline Boismann & $1518 \mathrm{v}$ & & & & & & \\
\hline Rotger Boismann & $\begin{array}{l}1506 \mathrm{v}- \\
1516 \mathrm{j}\end{array}$ & & $1517 \mathrm{v}$ & $1528 \mathrm{v}-1529 \mathrm{j}$ & & $1535-1542$ & 1545 \\
\hline Victor Bretholt & $\begin{array}{l}1524 \mathrm{j}- \\
1528 \mathrm{j}\end{array}$ & & $1528 \mathrm{j}$ & $1547 \mathrm{v}$ & $1547-1550$ & & $\begin{array}{l}\text { pärast } \\
1558\end{array}$ \\
\hline Bernt Bussmann & $\begin{array}{l}1502 \mathrm{v}- \\
1518 \mathrm{v}\end{array}$ & 29.10 .1518 & $1518 \mathrm{j}$ & $1532 \mathrm{v}-1533 \mathrm{j}$ & $1538-1541$ & & $1548 ?$ \\
\hline Hans Eckholt & $\begin{array}{l}1488 \mathrm{v}- \\
1494 \mathrm{v}\end{array}$ & & $1494 \mathrm{v}$ & $1506 \mathrm{v}$ & & $1511-1525$ & 1525 \\
\hline Hans Frilinck & $\begin{array}{l}1525 \mathrm{v}- \\
1526 \mathrm{j}\end{array}$ & & $1526 j$ & $1546 \mathrm{v}-1547 \mathrm{j}$ & & & 1559 \\
\hline Jurgen & $1516 \mathrm{j}-$ & & $1523 \mathrm{j}$ & $1534 \mathrm{j}$ & & $1536-1539$ & enne \\
\hline Gellinckhusen & $1523 \mathrm{j}$ & & & & & & 1544 \\
\hline Hans Hower & $1521 \mathrm{j}$ & 27.04 .1524 & $1523 \mathrm{j}$ & $1537^{106}$ & & $1539-1550$ & 1566 \\
\hline Gert Hulshorst & $\begin{array}{l}1514 \mathrm{j}- \\
1517 \mathrm{v}\end{array}$ & 06.11 .1524 & $1517 \mathrm{j}$ & $1543 \mathrm{j}-1544 \mathrm{v}$ & $1544-1547$ & & $1552 ?$ \\
\hline $\begin{array}{l}\text { Gert } \\
\text { Kampferbeck }\end{array}$ & $\begin{array}{l}1533 \mathrm{j}- \\
1536 \mathrm{j}\end{array}$ & 16.01 .1537 & $1537 \mathrm{v}$ & & $1560-1563$ & & \\
\hline $\begin{array}{l}\text { Hans } \\
\text { Kamnferbeck }\end{array}$ & $1523 \mathrm{v}-$ & 23.03 .1527 & $1526 \mathrm{v}$ & $1544 \mathrm{j}-1545 \mathrm{v}$ & & $1547-1562$ & $\begin{array}{l}\text { pärast } \\
1564\end{array}$ \\
\hline Kort Kardenal & $\begin{array}{l}1498 \mathrm{v}- \\
1502 \mathrm{v}\end{array}$ & 24.09 .1507 & $1503 \mathrm{j}$ & $1518 \mathrm{j}-1520 \mathrm{v}$ & $1529-1532$ & & 1549 \\
\hline Hans Kock & $\begin{array}{l}1502 \mathrm{v}- \\
1507 \mathrm{j}\end{array}$ & 27.10 .1508 & $1508 \mathrm{j}$ & & $1520-1521$ & $1521-1533$ & \\
\hline Bertold Kulle & $1515 \mathrm{j}$ & 26.05 .1508 & $1517 \mathrm{j}$ & $1545 \mathrm{v}-1546 \mathrm{j}$ & & & 1549 \\
\hline Israhel van Mer & $\begin{array}{l}1468 \mathrm{j}- \\
1474 \mathrm{v}\end{array}$ & 14.11 .1477 & $1475 \mathrm{v}$ & $1485 \mathrm{j}-1486 \mathrm{j}$ & 1491-1494 & 1485,1495 & 1496 \\
\hline Lambert Ottink & $\begin{array}{l}1473 \mathrm{j}- \\
1480 \mathrm{v}\end{array}$ & 17.11 .1480 & $\begin{array}{l}\text { tõenäol. } \\
\text { 1480-81 }\end{array}$ & $1494 \mathrm{j}-1496 \mathrm{v}$ & 1496-1499 & $1500-1514$ & $1515 ?$ \\
\hline Hans Peppersack & $\begin{array}{l}1479 \mathrm{j}- \\
1489 \mathrm{j}\end{array}$ & 15.03 .1492 & $1489 \mathrm{j}$ & $1502 \mathrm{j}-1504 \mathrm{v}$ & $1512-1514$ & & 1524 \\
\hline Mauritius Rotert & $\begin{array}{l}1511 \mathrm{v}- \\
1519 \mathrm{v}\end{array}$ & & $1519 \mathrm{v}$ & $1538 \mathrm{j}-1540 \mathrm{j}$ & & & 1547 \\
\hline $\begin{array}{l}\text { Hans } \\
\text { Tidinckhusen }\end{array}$ & $\begin{array}{l}1473 \mathrm{j}- \\
1483 \mathrm{j}\end{array}$ & & $1483 \mathrm{j}$ & $\begin{array}{l}1498 \mathrm{j}-1500 \mathrm{v} \\
1502 \mathrm{v}\end{array}$ & $1505-1508$ & & 1521 \\
\hline $\begin{array}{l}\text { Albert } \\
\text { Westermann }\end{array}$ & $1476 \mathrm{j}$ & 05.05 .1477 & $1476 \mathrm{j}$ & $1492 \mathrm{j}-1494 \mathrm{v}$ & 1499-1502 & & 1524 \\
\hline Hans Westhoff & $\begin{array}{l}1452 \mathrm{j}- \\
1456 \mathrm{v}\end{array}$ & 06.09 .1476 & $1456 \mathrm{j}$ & & $1485-1488$ & & 1503 \\
\hline
\end{tabular}

MP - Mustpeade vennaskond, SG - Suurgild, $\quad \mathrm{j}-$ jõulujoodud (märgitud algusaasta) ${ }^{107}$, v - vastlajoodud. 
Tabel 2. Tallinna Suurgildi oldermannid $1499-1560^{108}$

\begin{tabular}{lcccc}
\hline \multicolumn{1}{c}{ Nimi } & SG liige alates & Vahe aastates & Oldermann \\
\hline Albert Westermann & $1476 \mathrm{j}$ & 23 & $1499-1502$ \\
Hinrick Lussenberch & $1480 \mathrm{j}$ & 22 & $1502-1505$ \\
Hans Tidinckhusen & $1483 \mathrm{j}$ & 22 & $1505-1508$ \\
Hinrick Dellinckhusen & $1482 \mathrm{j}$ & 26 & $1508-1511$ \\
Hans Peppersack & $1489 \mathrm{j}$ & 22 & $1511-1514$ \\
Wolmer Brockhusen & $1501 \mathrm{v}$ & 13 & $1514-1517$ \\
Willem Rinckhoff & $1500 \mathrm{j}$ & 17 & $1517-1520$ \\
Hans Kock & $1508 \mathrm{j}$ & 12 & $1520-1521$ \\
Hans Selhorst & $1506 \mathrm{j}$ & 15 & $1521-1524$ \\
Bertold Bomhower & $1506 \mathrm{j}$ & 18 & $1524-1527$ \\
Jurgen von der Heide & $1514 \mathrm{j}$ & 13 & $1527-1529$ \\
Kort Kardenal & $1503 \mathrm{j}$ & 26 & $1529-1532$ \\
Valentin von Hagen & $1505 \mathrm{j}$ & 27 & $1532-1534$ \\
Helmich Ficke & $1513 \mathrm{v}$ & 22 & $1535-1538$ \\
Bernt Bussmann & $1518 \mathrm{j}$ & 20 & $1538-1541$ \\
Hinrick Boismann & $1518 \mathrm{j}$ & 23 & $1541-1544$ \\
Gert Hulshorst & $1517 \mathrm{j}$ & 27 & $1544-1547$ \\
Victor Bretholt & $1528 \mathrm{j}$ & 19 & $1547-1550$ \\
Goschalk Becker & $1529 \mathrm{j}$ & 21 & 1550 \\
Bertold Dobbin & $1531 \mathrm{j}$ & 20 & $1551-1554$ \\
Lutke van Oyten & $1533 \mathrm{j}$ & 21 & $1554-1557$ \\
Remmert von Scharenberg & $1537 \mathrm{j}$ & 20 & $1557-1560$ \\
& & & \\
\hline j - jõulujoodud (märgitud algusaasta) & $\mathrm{v}$ & & \\
& - vastlajoodud. & & \\
& & &
\end{tabular}

105 Allikad: TLA, f 87, n 1, s 20, s 21a; f 191, n 2, s 1, s 3, s 15, s 16; Bürgerbuch; RR 3; Bunge, F. G. v. Die Revaler Rathslinie. Raehärrasid puudutav andmestik on võetud peamiselt Bunge teosest ja võib olla mittetäielik.

106 Hans Howeri kohta on allikates vastukäivad teated: ühes allikas on teda nimetatud 1537. a kaasistujana (TLA, f 191, n 2, s 3, fol. 88r), seevastu ühe teise allika järgi oli sel aastal kaasistujaks hoopis Hans Knyper (s 15, pag. 289, 295).

107 Siin ja tabelis 2 on edastatud jõulujootude algusaasta. See võib allikas antud aastaarvust ühe aasta võrra erineda, sest jõulujoote tähistati valdavalt uue aasta numbriga. Põhjuseks polnud mitte see, et joodud lõppesid jaanuaris, vaid et hiliskeskajal loeti jõule mitmel pool, sh Saksa aladel, uue aasta alguseks ja aastanumber vahetus 25. detsembril. Vt Mänd, A. Pidustused, 88.

108 Allikad: TLA, f 191, n 2, s 1, s 15, s 16. 


\title{
ON THE MEMBERSHIP OF THE GREAT GUILD AND THE SOCIAL CAREER OF A MERCHANT IN LATE MEDIEVAL TALLINN
}

\author{
Anu MÄND
}

This article focuses on the membership of the Great Guild in medieval Tallinn (German Reval), the most influential association in the city. Scholars have thus far defined this guild as the association of wealthy merchants who were involved in wholesale and long-distance trade and who were burghers of the city. However, the analysis of sources proves that the membership of the guild was much more diverse.

Information on guild members can be gathered from normative sources (the guild statutes) as well as from those reflecting actual practice. The first among the latter is the account book of the Great Guild from 1509 till 1603, which includes the names of those attending the two main festivals, Christmas and Carnival, as well as those of the new members. The second is the book of brothers of the Table Guild from 1364 till 1549, listing the names of the new members. The Table Guild - a charitable association that distributed food to the poor - constituted a kind of sub-organization of the Great Guild. According to their statutes, membership of the Table Guild was limited to people belonging to the Great Guild.

A closer study of the names found in these two sources indicates that, in addition to merchants, the guild also admitted some clerics, above all priests from the Church of the Holy Spirit. Since the Table Guild operated at this church, the admission of those priests is quite understandable. The guild also admitted city scribes, some of whom belonged to the clergy as well. Another 'exceptional' group among the guild members were noblemen, some of them local but some from abroad (such as a knight from Denmark). Sea captains, both local and foreign, were admitted as well. Even a painter, who, in accordance with his profession should have been a member of the St Canute's Guild of the artisans, can be found in the lists of the Great Guild.

Scholars have frequently emphasized the fact that city councillors were elected from among members of the Great Guild alone. This is correct in the sense that members of the artisan guilds were never elected to the city council. It transpires, however, that some men first became city councillors and only thereafter entered the Great Guild. One possible explanation for this 'unusual' behaviour can be that they had lived and been elected councillors in some other city and at some point they moved over to the city council of Tallinn.

Surprisingly, among the new members of the Great Guild one can find several city councillors and burgomasters from other cities, such as Tartu (Dorpat), Narva, and New Pärnu (Neu Pernau). They continued to live and work in their own city. Hence, the guild also admitted men who were not burghers of Tallinn (the same is generally valid for clerics, foreign sea captains and noblemen).

In addition to guild brothers, there is also information on the guild sisters. However, female members did not have the same rights as men: they were never elected 
to any of the guild offices, they did not participate in the general meetings, and even at the time of festivals they were invited to the guildhall only on particular days. The guild took care of the wives and widows by providing financial support, if necessary, by organizing funerals, and by ordering masses and prayers for the souls of the deceased.

Hence, as the sources testify, the membership of the Great Guild was much more diverse than thus far assumed, and the guild cannot be regarded merely as an association of the merchants. It was a corporation of the urban elite, uniting the wealthy and/or the powerful, and also admitting 'foreigners' with appropriate status.

In the second part of the article, the social career of a merchant is analysed, by which is meant his movement from one association to another and his advancement within the guild hierarchy. This topic is closely related to the question of how the following turning points in a man's life - marriage, becoming a burgher, and entering the guild - were connected.

First, it is vital to explain the relations of the Great Guild with another merchants' association in Tallinn, the Brotherhood of the Black Heads. The latter was a journeymen's association, uniting mainly sons of the members of the Great Guild. However, the confraternity also admitted foreign merchants and sea captains. It was customary that when a Black Head married, he moved over to the Great Guild and took the burgher's oath. Of course, not every member of the Great Guild had formerly belonged to the Brotherhood of the Black Heads, and some Black Heads never entered the Great Guild. There is also evidence that, in certain periods, there were married men among the Black Heads as well as bachelors among the guild members. Nonetheless, the division between the two was generally made on the basis of marital status, burghership, and occupational status.

It can be said that a typical career for a merchant in Tallinn was that after turning eighteen, he entered the Brotherhood of the Black Heads and remained a member until his marriage (the average period spent in the confraternity was five years). Thereafter he was admitted to the Great Guild where he remained until his death. The highest social position he could achieve was that of city councillor or, higher still, the office of burgomaster.

Although the members of the Great Guild were addressed in documents as 'burghers' (in contrast to the Black Heads who were 'journeymen'), there seems to have been no strict rule that necessitated becoming a burgher before entering the Great Guild. There were indeed men who took the burgher's oath some months before joining the guild. However, there were plenty of others who took it afterwards, sometimes even years after becoming a guild member. Table 1 provides a short overview of the social career of some merchants, presenting the following information: name, years in the Brotherhood of the Black Heads, date of becoming a burgher, date (year and festival) of entering the Great Guild, period as an assessor of the guild, period as the alderman, years in the city council, and year of death. 
As the sources testify, in order to be elected alderman, one had to be in the guild for a minimum of twelve years. In practice, this period was usually longer around twenty years. When one looks at the list of aldermen of the Great Guild from 1499 until 1560 (Table 2), one can observe that four of them had been guild members for 26 or 27 years before being elected to the position of alderman. This confirms what is generally known about medieval guilds: their leaders were elected from among old (and thus presumably experienced) men. Consequently, it is clear that age was considered one of the preconditions for authority and power. City councillors were likewise elected from among elderly guild members, and many of them had formerly held high positions in the guild (an alderman or an assessor), thus proving themselves skilled in administrative matters.

By observing the movement of merchants from one association to another, and their careers within an association, one can outline the general patterns of a social career as well as detect deviations from the 'norm'. This, in turn, can help us better understand the system of social hierarchies in a medieval city, and also the role of guilds in the community. 